\title{
Golden Rice: A Path to Nutritional Security Achievement
}

ISSN: 2637-7659

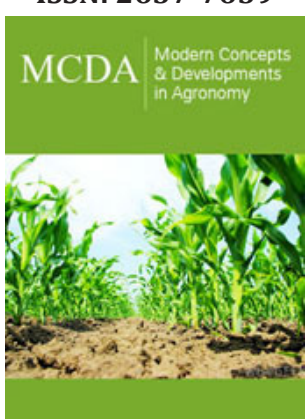

*Corresponding author:Sushan Chowhan, Senior Scientific Officer, ARED, BINA Substation, Ishurdi, Pabna, Bangladesh

Submission: 㭗 November 11, 2020

Published: 望 December 21, 2020

Volume 7 - Issue 4

How to cite this article: Sushan Chowhan, Md. Khan Jahan Ali, Kamrun Nahar, Md. Moshiur Rahman, Md. Imdadul Hoque, Majharul Islam. Golden Rice: A Path to Nutritional Security Achievement. Mod Concep Dev Agrono. 7(4). MCDA. 000670. 2020. DOI: 10.31031/MCDA.2020.07.000670

Copyright@ Sushan Chowhan, This article is distributed under the terms of the Creative Commons Attribution 4.0 International License, which permits unrestricted use and redistribution provided that the original author and source are credited.
Sushan Chowhan ${ }^{1 *}$, Md. Khan Jahan Ali $^{2}$, Kamrun Nahar ${ }^{2}$, Md. Moshiur Rahman $^{2}$, Md. Imdadul Hoque ${ }^{3}$ and Majharul Islam ${ }^{4}$

${ }^{1}$ Adaptive Research and Extension Division, Bangladesh Institute of Nuclear Agriculture, Substation, Ishurdi, Pabna-6620, Bangladesh.

${ }^{2}$ Plant Breeding Division, Bangladesh Institute of Nuclear Agriculture, Sub-station, Ishurdi, Pabna-6620, Bangladesh.

${ }^{3}$ Plant Breeding Division, Bangladesh Institute of Nuclear Agriculture, Mymensingh-2202, Bangladesh

${ }^{4}$ Soil Science Division, Bangladesh Institute of Nuclear Agriculture, Mymensingh-2202, Bangladesh

\begin{abstract}
Golden Rice (GR) is a special form of rice which comprises $\beta$-carotene (pro-vitamin A) in its grains. This was built through genetic engineering by inserting a combination of genes from daffodil (psy) and Erwinia (crtI) bacteria. Initially developed GR had a lower $\beta$-carotene content; later GR2E was made which had a total carotenoid up to $37 \mu \mathrm{g} / \mathrm{g}$ (23 times more than the earlier GR). Justification of GR consumption is mainly for combating nutrition hunger especially Vitamin A related deficiencies specifically night blindness. Bangladesh is a major rice growing country in the world where more than $60 \%$ of the food consumption is cereals. Resulting a higher consumption of rice (approximately $150 \mathrm{Kg} /$ year/person). Imbalance dietary habit of Bangalis is a major problem for nutrition requirement makeup. 144g/day consumption of GR may fulfil the daily need $\beta$-carotene thus, GR may play a crucial role to meet up this demand. IRRI has bio fortified BRRI dhan29 (a mega rice variety in Bangladesh) with GR's pro-vitamin A bearing genes. Field trials of GR with popular rice varieties were recorded to be completely environmental friendly without any significant distinction in yield except $\beta$-carotene content. Constrains of GR is mainly focused by some environmentalists which they assume to be loss of genetic resources, potential growth of secondary insect, disease, weeds, health issues etc. Though clinical trials with mice were found to be completely safe and toxic free with $\beta$-carotene feeding (grains) of GR. Presently GR is still under confined review and evaluation to be released as cultivation in farmer's level. As science advances by more and more variation and modification in food and crop will occur but it's up to us what we'll choose and eat to keep us healthy and sound.
\end{abstract}

Keywords: Golden rice; Bangladesh;Vitamin A deficiency; Bio fortified rice; BRRI dhan29

Abbreviations: GR: Golden Rice; GM: Genetically Modified; VAD: Vitamin A Deficiency; VA: Vitamin A; RDA: Recommended Dietary Allowance; RE: retinol equivalents; BRRI: Bangladesh Rice Research; IRRI: International Rice Research Institute; BARI: Bangladesh Agricultural Research Institute; BSFB: Brinjal Shoot and Fruit Borer

\section{Introduction}

Rice is the prime food for more than $50 \%$ of the world population. Golden rice is a kind of $\mathrm{GM}$ rice which is rich in $\beta$-carotene (precursor of vitamin A) and grains are light yellowish in color. Vitamin A deficiency (VAD) is one of the severe micronutrient deficiencies globally. It is the major cause of childhood blindness which is preventable at early stage [1]. Main cause of deficiency of this nutrient is not consuming vitamin A-rich foods. In Bangladesh, against the RDA of 300 RE requirement per children per day of under 5 years age consumption is 270 retinol equivalents (RE) of vitamin A. Women of childbearing age is intakes 372RE vitamin A whereas the RDA is 700RE [2]. Adults aging over 18 (considering average body weight of $60 \mathrm{Kg}$ for male and $50 \mathrm{Kg}$ for female) require $600 \mu \mathrm{g} /$ day vitamin A [3]. Bangladesh ranks $4^{\text {th }}$ in terms of rice production [4]. Mean total of 41,762,758.16 tons production was obtained during 1994-2018 period. Whereas national average yield was 3.03t/ha in 2018-19 [5]. The Bangalis eat $2 / 3^{\text {rd }}$ of the meal as rice and in some cases its 3 times. Thus, rice intake more than the other foods. Next is the pulse (lentil, mung, black gram etc.) intake. For the poorer, hand to 
mouth and laborers rice is the main food for relieving hunger and gaining nutrition. Due to high price of fruits and vegetables there's limited scope to buy VA enriched foods.

Therefore, most of the poor and people involved in hard labor work lack adequate knowledge on balanced food and nutrition. Per capita daily consumption of rice is almost 400g [6]; against the requirement of 1 cup rice (150g)/person/day [7]. Bangladesh ranks $4^{\text {th }}$ in terms of rice consumption after China, India and Indonesia [8]. On an average they consume a total of $126 \mathrm{~g}$ fruit and vegetables daily, which is far below recommended consumption of $400 \mathrm{~g}[9,10]$ To achieve SDG goal number 2 (end hunger, achieve food security and improved nutrition and promote sustainable agriculture) and 3 (Ensure healthy lives and promote well-being for all at all ages) it's essential to ensure balanced food and nutrition. Due to huge intake of rice there's a bright scope to eradicate VAD through golden rice consumption as it contains $3.57 \mu \mathrm{g} / \mathrm{g} \beta$-carotene (dry basis). Presently golden rice is at final trial stage by BRRI to be released. As, farmers of Bangladesh are choosy for varietal cultivation thus they won't adopt this super rice easily. As a result, BRRI is trying to fortify the popular varieties with VA through inserting the golden rice gene. Key goal of this review was to search for the prospect, problem and challenges to cultivate, adopt and accept the golden rice as GM crop in Bangladesh and how it may contribute to gain nutritional security for the greater people.

\section{Discussion}

Rice is produced in more than $3 / 4^{\text {th }}$ land area of Bangladesh [11]. It plays an emergent role for rural economy as well as abating hunger. Sociocultural, socioeconomic as well as climatic and topographic conditions permits the abundant cultivation of this cereal crop [12]. It provides $27 \%$ of dietary energy and $20 \%$ of the dietary protein in the developing world [9] and contributes over $70 \%$ of total production and $60-94 \%$ of daily calorie intake in Bangladesh, India, Nepal, Pakistan and China [10]. One cup (158g) of cooked boil rice contains the essential food components about $44.5 \mathrm{~g}$ carbohydrate, $4.2 \mathrm{~g}$ of protein, $0.4 \mathrm{~g}$ total fat, $0.1 \mathrm{mg}$ vitamin $\mathrm{E}$, $0.3 \mathrm{mg}$ Thiamin, 2.3mg Niacin, 0.1mg Vitamin B6, 91.6mcg Folate, $0.6 \mathrm{mg}$ Pantothenic Acid, 3.3mg Choline, $0.5 \mathrm{mg}$ Betaine. Major minerals like calcium (15.8mg), Iron (1.9mg), Magnesium (19.0mg), Phosphorus (68.0mg), Potassium (55.3mg), Sodium (1.6mg), zinc (0.8mg), copper $(0.1 \mathrm{mg})$, manganese $(0.7 \mathrm{mg})$ and water $(108 \mathrm{~g})$ [7].

GR was developed in the late 1990s by German plant scientists Ingo Potrykus and Peter Beyer to fight VAD. It was the world's first VA enriched rice varieties to introduce a new era in the combat against VAD [13]. GR is an engineered type of rice that generates $\beta$-carotene (pro-vitamin A) for fighting vitamin A deficiency [14]. It was predicted that contribution GR to eradicate vitamin A deficiency would be higher as it contained $\beta$-carotene [15]. The first GR was developed through daffodil gene encoding phytoene synthase (psy), which had limited amount of VA accumulation. Later psy from maize was found to produce increased carotenoid. In 2005, GR2E rice was developed by using of recombinant-DNA techniques. GR2 was modified through combination of psy from maize and carotene desaturase (crtI) from Erwinia uredovora to express elevated levels of provitamin A [14]. This increased the total carotenoids up to 23fold (maximum $37 \mu \mathrm{g} / \mathrm{g}$ ) than the original parental (initial) GR and a significant accumulation of $\beta$-carotene. On average, $144 \mathrm{~g} /$ day of the high-yielding strain would have to be eaten to meet the daily requirement of VA. Bioavailability of carotene from GR is already confirmed and reported to be a useful source of vitamin A for humans [16].

Single biological difference between GR2E and control rice is in the levels of $\beta$-carotene and other provitamin A carotenoids in the grain. Except for $\beta$-carotene and related carotenoids, other compositional parameters of GR2E are within the range likewise traditional rice varieties with a history of purely safe consumption. Mean provitamin A concentrations in milled rice of GR2E can contribute up to $89-113 \%$ and $57-99 \%$ of the estimated average requirement for vitamin $\mathrm{A}$ for preschool children in Bangladesh and the Philippines, respectively [17]. $\beta$-Carotene is generally considered virtually nontoxic as humans tolerate high dietary dosages without apparent harm [18] and there's no report of adverse effects arising from the consumption of naturally occurring $\beta$-carotene in food. Similarly, there is no proof that conversion of $\beta$-carotene to VA contributes to vitamin A toxicity, even when $\beta$-carotene is ingested in large amounts. Standard toxicological tests, including teratogenic, mutagenic, and carcinogenic assays, have been performed on $\beta$-carotene without any record of detrimental effects [19]. Yield difference with popular cultivars along with GR2E are not statistically significant.

No indications on GR2E rice noticed that its fitness make it more invasive or persistent in the environment or have altered susceptibility to pests or diseases, than conventional rice varieties. No sequence homology structural alerts for potential toxicity and allergenicity of the ZmPSY1 protein were figured. Feeding trials with male and female mice at $100 \mathrm{mg} / \mathrm{kg}$ did not lead to mortality or other evidence of acute oral toxicity or disorders. Nutritional composition of GR2E like fibre, polysaccharide, ash, crude fat, protein, minerals, carotenoids and straw composition are very similar to normal rice except carotenoid. As the genes are endosperm specific so, it expresses only in grain, not in other parts of the plant [20]. United States, Canada, New Zealand, and Australia has already approved GR for consumption. At present, the GR is under confined review in Bangladesh at IRRI in Los Baños, Philippines. Breeders inserted beta-carotene genes into BRRI dhan29, which contributes almost $14 \%$ of the national harvest. Multi location trials of BRRI dhan29 GR by BRRI in Gazipur reported no new farming challenges and significant differences in quality except presence of VA. BRRI submitted these data to the Ministry of Environment, Forest, and Climate Change in November 2017 and the biosafety core committee is reviewing potential environmental risk factors such as plant's potential to become a weed, food safety concerns, loss of genetic resources, diversity etc. In 2014 BARI launched GM brinjal varieties to protects fruits from BSFB which 
offered rapid benefit to the farmers by not applying insecticide. In initial stage government may have to subsidize farmers to grow GR but consumer acceptance is a big challenge, because people have a preference of color of food they eat. The Bangalis prefer cooked rice color as white. Contrary, cooked GR resembles 'khichuri', a popular dish of rice and lentils cooked with turmeric, salt, oil, onion, chili, garlic which might increase its petition [21].

\section{Conclusion}

Though GR was developed approximately 20 years ago but its suitability, necessity and finally consumption are still in debate by the scientific community specially the environmentalists and oppositionists. Undoubtedly, GR is a blessing of modern science in fighting nutrition hunger for the third world countries yet more research, analysis, public knowledge, awareness, perception and finally religious issues are a matter of concern for GR's successful dissemination and sustainability. If everything is favorable, we hope to plant GR soon.

\section{References}

1. Wirth JP, Petry N, Tanumihardjo SA, Rogers LM, McLean E, et al. (2017) Vitamin A supplementation programs and country-level evidence of vitamin A deficiency. Nutrients 9(3): 190.

2. Mostafa I, Islam SF, Mondal P, Faruque ASG, Ahmed T, et al. (2019) Factors affecting low coverage of the vitamin A supplementation program among young children admitted in an urban diarrheal treatment facility in Bangladesh. Global Health Action 12(1): 1588513.

3. AIS, Agricultural Information Service (2019) Krishi Dairy. Agril Inform Ser, Kamarbari, Farmgate, Dhaka, Bangladesh, p. 100.

4. FAOSTAT, Food and Agriculture Organization Corporate Statistical Database (2020) In: Crops.

5. BBS, Bangladesh Bureau of Statistics (2019) Yearbook of agricultural statistics. $31^{\text {st }}$ series, Forty-Five Years Production Statis-tics of Rice (Husked Rice), pp. 49-77.

6. Yunus M, Rashid S, Chowdhury S (2019) Per capita rice consumption in Bangladesh: Available estimates and IFPRI's validation survey results. IFPRP Working Paper 3, International Food Policy Research Institute (IFPRI), Washington, D.C, USA, pp. 1-18.

7. BIRTAN, Bangladesh Institute of Research and Training on Applied
Nutrition (2015) Nutrition contents of Bangladeshi foods (In Bengali). Madina printers and publishers, Katabon, Dhaka, Bangladesh. p. 4.

8. Statista (2020) Global rice consumption 2019/20, by country.

9. FAO, Food and Agriculture Organization of the United Nations (2004) Human energy requirements. Report of a Joint FAO/WHO/UNU Expert Consultation, FAO Food and Nutrition Technical Report. Series No. 1, Rome, Italy.

10. Haque MM, Majumder RR, Hore TK, Biswash MR (2015) Yield contributing characters effect of submerged water levels of boro rice (Oryza sativa L.). Scientia Agriculturae 9(1): 23-29.

11. AIS, Agricultural Information Service (2011) Krishi Dairy, Agril Inform Ser, Kamarbari, Farmgate, Dhaka, Bangladesh, p. 23.

12. Chowhan S, Hoque MI, Ghosh SR, Islam M, Akter MB (2019) Effect of variety and seedling number on the growth and yield of boro rice in Bangladesh. Journal of Experimental Agriculture International 41(6): $1-15$.

13. The Asian Age (2020) Approval of golden rice for production and consumption.

14. Ye X, Babili SA, Klöti A, Zhang J, Lucca P, et al. (2000) Engineering the provitamin $A$ ( $\beta$-carotene) biosynthetic pathway into (carotenoid-free) rice endosperm. Science 287(5541): 303-305.

15. Zimmerman R, Qaim M (2004) Potential health benefits of Golden Rice: a Philippines case study. Food Policy 29(2): 147-168.

16. Paine JA, Shipton CA, Chaggar S, Howells RM, Kennedy MJ, et al. (2005) Improving the nutritional value of Golden Rice through increased provitamin A content. Nature Biotechnology 23: 482-487.

17. Swamy BPM, Samia M, Boncodin R, Marundan S, Rebong DB, et al. (2019) Compositional analysis of genetically engineered GR2E "Golden Rice" in comparison to that of conventional rice. J Agric Food Chem 67(28): 7986-7994.

18. Hathcock JN, Hattan DG, Jenkins MY, McDonald JT, Sundaresan PR, et al. (1990) Evaluation of vitamin A toxicity. Am J Clin Nutr 52(2): 183-202.

19. EFSA (2012) Scientific opinion on the re-evaluation of mixed carotenes (E 160a (i) and beta-carotene (E 160a (ii)) as a food additive. EFSA Journal 10(3): 2593.

20. Kader MA, Biswas PS, Ahmed HU, Hossain MA, Islam MR, et al. (2018) Updates of golden rice research in Bangladesh. A seminar held in BRRI auditorium.

21. Stokstad E (2019) Bangladesh could be the first to cultivate Golden Rice, genetically altered to fight blindness.

For possible submissions Click below: 